\title{
Anti-oxidant, Anti-inflammatory, and Anti-obesity Effects of Ethanol Extracts from Ulmus divididiana var. japonica
}

\author{
Sung-Gyu Lee ${ }^{*}$ and Hyun Kang ${ }^{\dagger ; *}$ \\ Department of Medical Laboratory Science, College of Health Science, Dankook University, \\ Cheonan-si, Chungnam 31116, Korea
}

\begin{abstract}
In this study, the anti-oxidant, anti-inflammatory, and anti-obesity activities of an ethanol extracts of Ulmus divididiana var. japonica (UDE) were investigated in vitro and in vivo. UDE anti-oxidant activity was evaluated with an Electron Spin Resonance (ESR) spectrometer, which measured 1, 1-diphenyl-2-picryl-hydrazyl (DPPH) radical scavenging activity. Cell viabilities were estimated using 3-[4,5-Dimethylthiazol-2-yl]-2,5-diphenyl-tetrazolium bromide (MTT) assay. LPS-stimulated BV-2 microglia were used to study the production of nitric oxide (NO). Cells stimulated with LPS produce more NO than normal control cells. However, cells treated with the UDE decreased this production in a concentration dependent manner $(100,250,500,1,000 \mu \mathrm{g} / \mathrm{mL})$. Also, we investigated the anti-obese activity of UDE in SD rats. The SD rats were randomly divided into five groups: $10 \%$ low fat diet $(\mathrm{N}), 45 \%$ high fat diet $(\mathrm{H}), 45 \%$ high fat diet + garcinia extracts $200 \mathrm{mg} / \mathrm{kg} /$ day (HG200), high fat diet + UDE $200 \mathrm{mg} / \mathrm{kg} /$ day (HU200), high fat diet + UDE 400 $\mathrm{mg} / \mathrm{kg} /$ day (HU400). UDE was found to lower whole body and abdominal and epididymal adipose tissue weights and lowered plasma levels of triglyceride (TG), compared to those in $\mathrm{H}$ group. Histological analyses of the liver and fat tissues of rat treated with UDE revealed significantly decreased number of lipid droplets and decreased size of adipocytes compared to the H group. These results suggest that UDE might be used to develop potent anti-oxidant, anti-inflammatory, and anti-obesity agents, and may be useful as ingredients for related new functional raw materials.
\end{abstract}

Key Words: Ulmus divididiana var. japonica, Anti-oxidant, Anti-inflammatory, Anti-obesity, Functional raw materials

\section{서 론}

느릅나무과(Ulmaceae)에 속하는 느릅나무(Ulmus divididiana var japonica)는 낙엽교목으로 느릅나무의 껍질을 건조한 것을 유백피, 뿌리의 껍질을 유근피라 한다 $(\mathrm{Ji}$ and Lee, 1988). 문헌에 따르면, 느릅나무는 유선염, 임질, 수 종과 같은 질병에 소염제로 이용되어 왔으며(Shin, 1977), 특히 유근피는 항암작용(Yang et al., 1996), 항균작용, 항염
(Hong el al., 1990)과 같은 생리활성 효과가 보고되었다. 이외 유근피의 성분에 대한 연구로는 이(Lee et al., 2001) 등이 유근피에서 lyoniside, 5'-methoxyioslariciresinol-9'- $O-\beta$ D-xylopyranoside, isolariciresinol-9'-O- $\beta$-D-xylopyranoside, reltrans-dihydrodehydroconiferyl alcohol 4'-O- $\alpha$-rhamnoside, icariside E3 등의 lignan 및 neolignan을 분리하였다. 유근피가 민간요법으로 현재까지 다양한 질병의 예방에 사용되어지 고 있다는 점은 새로운 기능성 신소재 개발 가능성이 높 은 소재로 평가되고 있다.

Received: August 5, 2019 / Revised: September 18, 2019 / Accepted: September 19, 2019

*Professor.

${ }^{\dagger}$ Corresponding author: Hyun Kang. Department of Medical Laboratory Science, College of Health Science, Dankook University, Cheonan-si, Chungnam, 31116 , Korea.

Tel: +82-41-550-3015, Fax:+82-41-559-7934, e-mail: hkang@dankook.ac.kr

(C) The Korean Society for Biomedical Laboratory Sciences. All rights reserved.

@This is an Open Access article distributed under the terms of the Creative Commons Attribution Non-Commercial License (http://creativecommons.org/licenses/by-nc/3.0/) which permits unrestricted non-commercial use, distribution, and reproduction in any medium, provided the original work is properly cited. 
노화와 여러 질병의 원인이 되고 있는 활성산소는 산화 적 스트레스의 영향으로 생성되며, superoxide anion radical $\left(\mathrm{O}_{2}{ }^{-}\right)$, 과산화수소 $\left(\mathrm{H}_{2} \mathrm{O}_{2}\right)$, hydroxyl $\mathrm{radical}(\cdot \mathrm{OH})$, lipid peroxide $(\mathrm{ROOH})$ 등의 종류가 있다(Wefers et al., 1984). 이들 활성산 소들은 고혈압, 고지혈증, 염증반응에서 세포신호 전달과 정을 유도하고 직접적인 조직 손상을 유발하며 혈관기능 을 저하시킨다(Talalay and Benson, 1982; Ohara et al., 1993). 일반적인 항산화제로 butylated hydroxyanisole (BHA) 혹은 butylated hydroxytoluene (BHT)와 같은 합성 물질이 이용되 어 왔으나, 과량 섭취할 경우 순환계, 간, 신장, 폐, 위장점 막 등에 심각한 독성을 유발하는 것으로 알려져 있어, 이 를 대체할 안전한 소재 개발이 요구되고 있다.

또한 염증반응은 물리적 혹은 화학적 자극에 의한 외상 이나 박테리아나 바이러스 같은 외부 물질이 체내로 유입 되었을 때 체내 면역방어기전의 일종으로 이물질을 공격 하기 위해 free radical을 생성하여 생체 방어에 중요한 역 할을 한다(Takeshi et al., 2010). 하지만 비정상적인 염증반 응은 염증매개체의 활성을 과도하게 일으키고, 이는 다양 한 염증성 질환들을 유발하게 된다(Tak and Firestein, 2001).

비만은 만성질환인 당뇨병, 암, 고혈압, 심혈관계질환과 같은 질환의 발병과 사망률을 증가시키는 원인으로 알려 져 있다(Bray, 2000). 비만은 환경적, 유전적, 사회적 요인 등 다양한 원인들에 의해 발생되며 에너지 과잉 섭취와 육체활동 감소로 신체 내의 에너지 불균형이 일어나 체조 직에 과도한 지방이 축적되어 나타나는 현상으로, 전세계 적으로 급속도로 확산되고 있어(Kopelman, 2000), 항비만 에 관련된 안전한 치료제 개발이 절실하게 요구되고 있는 실정이다(Jahromi et al., 1993). 같은 대사성 증후군은 질병 으로 분류하기 어려우며, 현재 사용하고 있는 항비만 의 약품의 부작용을 감안한다면 안전하고 증상을 개선할 수 있는 식품의약이 절실한 분야이다.

따라서, 본 연구에서는 유근피 추출물에 의한 항산화, 항염증, 항비만 등 다양한 생리활성 효과를 연구하였다. 이러한 연구는 유근피를 활용한 다양한 생리활성 기능성 신소재를 발굴하기 위해 수행하였다.

\section{재료 및 방법}

\section{실험재료 및 추출방법}

본 연구에 사용된 유근피는 서울약령시장에서 건조된 약재를 구입하여 사용하였다. 건조된 유근피를 200 mesh 이하로 조분쇄하여 시료 $100 \mathrm{~g}$ 과 $70 \%$ 에탄올 $1 \mathrm{~L}$ 를 혼합
하여 상온에서 3일 동안 추출한 후 Whatman filter paper (No. 1 \& 3)로 여과하였다. 여과된 추출액을 감압농축기 (N-1000S-WD, Eyela Co., Tokyo, Japan)를 이용하여 $55^{\circ} \mathrm{C}$ 수 욕상에서 용매를 제거하고, 동결건조(FDU-1100, Eyela Co., Tokyo, Japan) 후 실험에 사용하였다. 유근피 에탄올 추출 물의 추출 수율은 $11.3 \%$ 로 나타났다.

\section{총 페놀 및 플라보노이드 함량 측정}

총 페놀 함량은 Folin-Denis법(Folin and Denis, 1912)을 응 용하여 측정하였다. 유근피 추출물에 2배 희석한 FolinCiocalteu 시약을 동량 혼합하여 3 분간 반응시킨 후, $10 \%$ $\mathrm{Na}_{2} \mathrm{CO}_{3}$ 용액을 동량 가하여 1시간 정치시킨 후 ELISA reader (TECAN, Salzburg, Austria)를 사용하여 $700 \mathrm{~nm}$ 에서 흡광도를 측정하였다. 이때, 총 페놀 함량은 gallic acid를 이용하여 얻은 검량선을 이용하여 산출하였다.

총 플라보노이드 함량은 Nieva Moreno 등(Nieva Moreno et al., 2000)의 방법을 응용하여 측정하였다. 추출물 $1 \mathrm{mg}$ $/ \mathrm{mL}$ 의 농도로 $80 \%$ 에탄올에 녹여서 $100 \mu \mathrm{L}$ 를 취한 뒤 $10 \%$ aluminium nitrate와 $1 \mathrm{M}$ potassium acetate를 각각 $20 \mu \mathrm{L}$ 첨가한 후 $80 \%$ 에탄올을 $860 \mu \mathrm{L}$ 첨가 후 실온에서 40 분 반응시킨 후 $415 \mathrm{~nm}$ 의 흡광도로 측정하였다. 이때, 총 플 라보노이드 함량은 quercetin을 이용하여 검량선을 작성하 였다.

\section{$\alpha-\alpha$-Diphenyl- $\beta$-picrylhydrazyl (DPPH) radical 소거}

\section{활성}

유근피 추출물의 DPPH radical 소거활성은 추출물 용 액 $30 \mu \mathrm{L}$ 와 메탄올에 용해한 $60 \mu \mathrm{M} \mathrm{DPPH}$ 용액 $30 \mu \mathrm{L}$ 를 각각 가하고, 상온에서 2 분 동안 반응시켜 capillary tube에 옮긴 다음 electron spin resonance (ESR) spectrometer (JESPX 2300, JEOL, Akishima, Japan)로 측정하였다. 이 때 ESR spectrophotometer의 측정조건은 magnetic field, $337.394 \pm$ $7.5 \mathrm{mT}$; power, $5 \mathrm{~mW}$; sweep time, $30 \mathrm{sec}$; sweep width, $10 \mathrm{mT}$; modulation width, $0.8 \mathrm{mT}$; amplitude, 1,000 으로 설정하여 측 정하였다. 추출물에 대한 DPPH free radical 저해 활성(\%) 은(ESR signal intensity for medium containing the additives of concern/ESR signal intensity for the control medium) X100으 로 계산하였다.

\section{Mouse microglia BV-2 cell 배양}

Mouse microglia BV-2 cells은 ATCC에서 동결상태로 구 입하였으며 $10 \%$ fetal bovine serum (FBS; Gibco, BRL, USA), 
penicillin $\mathrm{G}(100 \mathrm{IU} / \mathrm{mL})$, streptomycin $(100 \mu \mathrm{g} / \mathrm{mL})$ 을 포함한 RPMI1640 배지 (Gibco, BRL, USA)를 이용하여 $37^{\circ} \mathrm{C}$ 와 $5 \%$ 의 $\mathrm{CO}_{2}$ 를 공급하는 배양기에서 배양하였으며, 1 2일 마다 세포의 성장 정도에 따라 계대 배양하였다.

\section{MTT assay}

LPS로 자극된 BV-2 cells에 대한 유근피 추출물의 세 포 독성 및 실험 시 처리 농도를 결정하기 위해 3-[4,5Dimethylthiazol-2-yl]-2,5-diphenyl-tetrazolium bromide (MTT) assay를 시행하였다. BV-2 cells을 RPMI1640 배지 $1 \mathrm{~mL}$ 당 $5 \times 10^{5}$ 개로 96 well plate에 $100 \mu \mathrm{L}$ 씩 분주하여 12 시간 동 안 배양하여 cell들이 부착되도록 하고, $100 \mathrm{ng} / \mathrm{mL}$ 의 LPS 가 첨가된 새 배지 $180 \mu \mathrm{L}$ 와 농도별로 희석한 유근피 추 출물 $20 \mu \mathrm{L}$ 를 첨가하였다. 24시간 배양 후, MTT를 최종 농도가 $0.5 \mathrm{mg} / \mathrm{mL}$ 가 되게 첨가한 후, 4 시간 동안 배양하여 보라색으로 생성된 formazan을 dimethylsulfoxide (DMSO) $100 \mu \mathrm{L}$ 첨가하여 용해시킨 후, ELISA reader를 이용하여 $540 \mathrm{~nm}$ 에서 흡광도를 측정하였다(Mosmann, 1983). 세포 생존율은 LPS를 처리하지 않은 대조군과 비교하여 백분 율(\%)로 나타내었다.

\section{Nitric oxide (NO) 생성 저해작용 측정}

Nitric oxide 생성 저해작용은 Griess의 방법(Green et al., 1982)으로 측정하였다. 즉, Griess 시약(1\% sulfanilamide, $0.1 \%$ naphthylethylendiaminein $25 \%$ phosphoric acid)은 NO 를 산화시켜 $\mathrm{NO}_{2}$ 로 변화시키며 생성된 $\mathrm{NO}_{2}$ 는 $540 \mathrm{~nm}$ 에 서 흡광도를 측정하며, $\mathrm{NaNO}_{2}$ 를 이용하여 검량선을 구하 였다. 즉, BV-2 cell을 RPMI1640 배지 $1 \mathrm{~mL}$ 당 $5 \times 10^{5}$ 개로 96 well plate에 $100 \mu \mathrm{L}$ 씩 분주하여 12시간 동안 배양하여 cell들이 부착되도록 하고, $100 \mathrm{ng} / \mathrm{mL}$ 의 LPS가 첨가된 새 배지 $180 \mu \mathrm{L}$ 와 농도별로 희석한 유근피 추출물 $20 \mu \mathrm{L}$ 를 첨가하여 24시간 배양 후, 배양액에 생성되어 있는 $\mathrm{NO}$ 의 양을 Griess 시약을 이용하여 측정하였다.

\section{실험동물의 사육 및 실험식이}

실험동물은 대한바이오링크(Korea)로부터 5주령(120 $150 \mathrm{~g}$ )의 Sprague-Dawley (SD)종 수컷 흰쥐 30마리를 구 입하여 사용하였다. 사육실 온도는 $23 \pm 2{ }^{\circ} \mathrm{C}$, 상대습도는 $60 \pm 5 \%$ 를 유지시키고, 명암은 12시간 주기로 일정하게 유지하였다. 처음 1 주일간 pellet형의 lab chow 식이를 제 공하면서 적응시킨 후, 8 주간 실험을 실시하였다. 실험군 은 Table 1 과 같이 $10 \%$ 지방이 함유된 저지방식이군 $(\mathrm{N})$,
Table 1. Experimental groups

\begin{tabular}{|c|c|c|}
\hline Group & Diet & Sample \\
\hline $\mathrm{N}$ & $10 \%$ low fat diet & DW \\
\hline $\mathrm{H}$ & $45 \%$ high fat diet & DW \\
\hline HG200 & $45 \%$ high fat diet & Garcinia extracts $200 \mathrm{mg} / \mathrm{kg}$ \\
\hline HU200 & $45 \%$ high fat diet & $\begin{array}{l}\text { Ulmus divididiana var. japonica } \\
\text { extracts } 200 \mathrm{mg} / \mathrm{kg}\end{array}$ \\
\hline HU400 & $45 \%$ high fat diet & $\begin{array}{l}\text { Ulmus divididiana var. japonica } \\
\text { extracts } 400 \mathrm{mg} / \mathrm{kg}\end{array}$ \\
\hline
\end{tabular}

$45 \%$ 고지방식이군 $(\mathrm{H}), 45 \%$ 고지방식이+가르시니아 추 출물 $200 \mathrm{mg} / \mathrm{kg} / \mathrm{day}$ 군(HG200), $45 \%$ 고지방식이+유근피 추출물 $200 \mathrm{mg} / \mathrm{kg} / \mathrm{day}$ 군(HU200), $45 \%$ 고지방식이+유근피 추출물 $400 \mathrm{mg} / \mathrm{kg} / \mathrm{day}$ 군(HG400)으로 나누어 실험하였다. 각 군별 6 마리의 흰쥐를 사용하였으며, 식이와 증류수는 자유 섭취시켰으며 가르시니아 및 유근피 추출물의 시험 약물은 일정한 시간 경구투여 하였다. 식이 섭취량은 일 주일 간격으로 조사하여 식이 섭취량(g/day)을 산출하였 으며, 체중은 매주 일정한 시간에 측정하였다. 본 동물실 험은 단국대학교 동물실험 윤리위원회 승인을 획득한 후 실시하였다.

\section{혈액 및 장기 수집}

12 시간 절식시킨 흰쥐를 에테르로 마취시켜 해부하였 다. 복부대동맥으로부터 혈액을 채취하여, 원심분리 후 혈 청을 분리, $-70^{\circ} \mathrm{C}$ 에서 냉동보관 하였다. 희생 후 즉시 간, 신장, 비장과 복부지방, 부고환지방도 적출하여 생리식염 수에 세척한 후 여과지로 수분을 제거하여 무게를 측정 하였다.

\section{혈액의 생화학적 분석}

혈청분석 항목은 총 콜레스테롤, 중성지방, $\mathrm{HDL}$-콜레 스테롤로써 자동혈액분석기(Konelab20XT, Thermo, MA, USA)로 분석하였다. 혈청의 LDL-콜레스테롤은 분석을 통해 얻은 총 콜레스테롤, $\mathrm{HDL}$-콜레스테롤 그리고 중성 지방의 수치를 이용하여 아래의 계산식에 의해 계산하였 다(Friedewald et al., 1972).

LDL-콜레스테롤 = 총 콜레스테롤-(HDL-콜레스테롤 + 중성지질/5) 


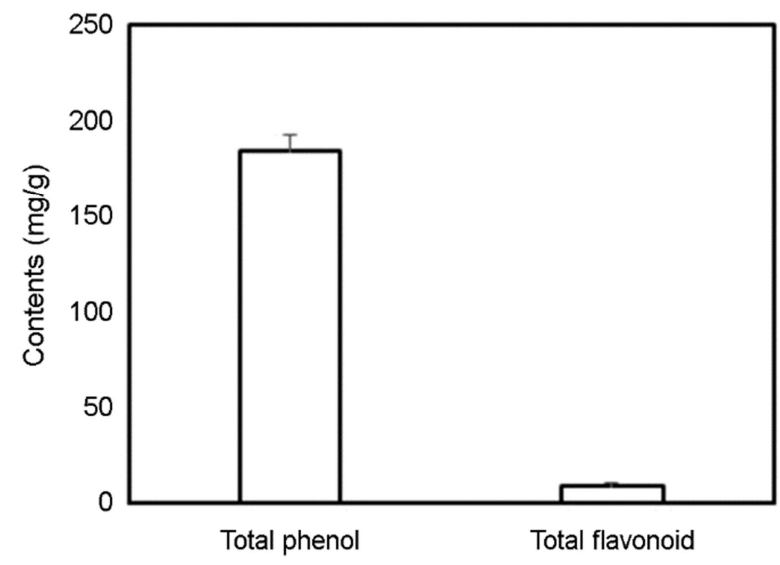

Fig. 1. Total phenolic and flavonoid contents of UDE (Ulmus divididiana var. japonica extracts).

\section{간과 복부지방 조직의 형태학적 관찰}

흰쥐에서 적출한 간, 복부지방을 $10 \%$ neutral buffered formalin을 사용하여 24시간 동안 고정한 후 탈수 및 포매 과정을 걸쳐 $4 \mu \mathrm{m}$ 두께의 파라핀 절편을 제작하였다. 파 라핀 절편은 xylene으로 파라핀을 제거시키고, 하강 계열 알코올로 친수화 시킨 후 hematoxylin-eosin (H\&E)으로 염 색하여 광학현미경(Olympus, Japan)으로 관찰하였다(Yuan et al., 2008).

\section{통계분석}

실험결과는 SAS program (SAS institute, Inc. SAS/SAAT user's Guide. Version $6,4^{\text {th }}$ ed. Cary, NC, USA)을 이용하여 분산분석한 후 유의성이 있는 항목에 대해서는 Duncan's multiple range test로 $P<0.05$ 수준에서 시료간의 유의성을 검정하였다.

\section{결 과}

\section{총 페놀 및 플라보노이드 함량}

본 연구에서는 총 페놀과 플라보노이드의 표준 물질로 보편적으로 잘 활용되고 있는 gallic acid와 quercetin을 각 각 사용한 검량선으로부터 유근피 추출물의 총 페놀 및 플라보노이드 함량을 확인하였다. 그 결과, 유근피 추출물 내의 페놀 및 플라보노이드 함량은 Fig. 1 과 같이 각각 $184.68,9.25 \mathrm{mg} / \mathrm{g}$ 의 농도로 함유하고 있음을 확인하였다.
A

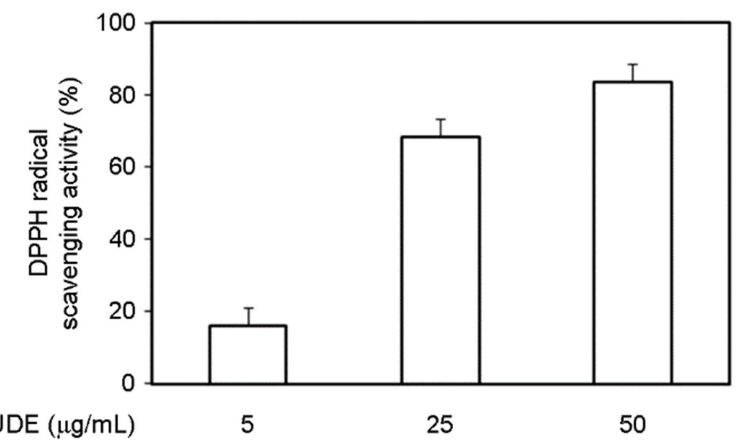

B

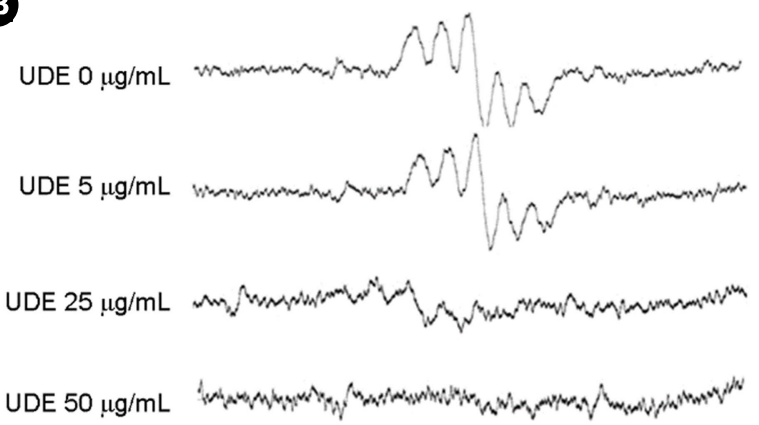

Fig. 2. Effect of UDE (Ulmus divididiana var. japonica extracts) on DPPH radical scavenging activity. The capacity scavenge DPPH free radicals at different concentrations UDE (A), shown to vary through ESR spectra (B) measurements.

\section{$\mathrm{DPPH}$ radical 소거활성 효과}

유근피 추출물의 항산화능을 측정하기 위해 DPPH radical 소거활성을 측정한 결과는 Fig. 2 와 같다. 유근피 추 출물을 각각 $5,25,50 \mu \mathrm{g} / \mathrm{mL}$ 의 농도로 처리하여 $\mathrm{DPPH}$ radical 소거능을 백분율로 나타낸 결과, 각각 $18.24,63.97$, $82.15 \%$ 의 소거능을 보였다(Fig. 2A). 또한, ESR spectrometer 로 얻어낸 결과로 peak의 높이를 control과 비교하였을 때, 농도의존적으로 peak 높이가 낮아지는 것을 확인하였다

(Fig. 2B).

\section{세포 독성 및 NO 생성 저해 효과}

유근피 추출물의 염증성 질환 개선 소재로서 활용 가능 성을 확인하기 위해 BV-2 microglia cell line에 LPS로 유 도된 NO 생성 저해능을 실험하기에 앞서 실험에 사용된 유근피 추출물 $100 \sim 1,000 \mu \mathrm{g} / \mathrm{mL}$ 의 모든 농도에서 MTT assay를 통해서 세포 독성을 확인한 결과 Fig. 3 과 같이 모 든 농도에서 세포생존율이 $90 \%$ 이상으로 유근피 추출물 의 세포 독성이 관찰되지 않았다. 유근피 추출물의 NO 생 
성 저해 효과를 측정한 결과는 Fig. 4에 나타내었다. LPS 를 처리하지 않은 경우 약 $2.91 \mu \mathrm{M}$ 의 낮은 농도로 $\mathrm{NO}$ 가 존재하지만, $\mathrm{LPS}$ 를 처리한 군의 경우 $23.12 \mu \mathrm{M}$ 로 약 7 배 이상 NO 생성이 증가됨을 확인하였다. 이에 반해, 유 근피 추출물을 처리하였을 경우 농도의존적으로 $\mathrm{NO}$ 생 성이 감소되는 것을 확인하였고, 특히 $1,000 \mu \mathrm{g} / \mathrm{mL}$ 의 농 도에서는 LPS 처리하지 않은 군과 유사한 경향을 보여 유근피 추출물은 강력한 NO 생성 저해 효능이 있음을 확 인하였다.

\section{유근피 추출물이 고지방으로 유도된 흰쥐의 체중변화 및 식이 섭취량에 미치는 영향}

유근피 추출물의 비만 유도된 흰쥐에 있어서 비만의 개선에 미치는 영향을 조사하기 위해 실험동물의 체중 증 가량, 식이 섭취량 및 식이효율을 측정한 결과는 Table 2 에 나타내었다. 8주 후 각 군별의 체중 증가량은 저지방

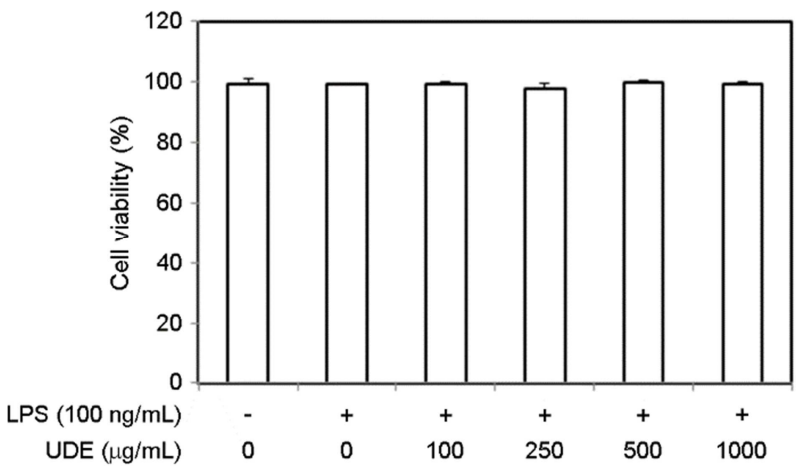

Fig. 3. UDE's (Ulmus divididiana var. japonica extracts) effect on microglial BV-2 cells using MTT assay. The results are displayed in percentages relative to control sample without LPS/UDE treatment.
식이 $\mathrm{N}$ 군과 비교하여 고지방식이 $\mathrm{H}$ 군에서 유의적으로 증가하였다. 고지방식이에 양성대조군인 가르시니아 추출 물(HG200)과 유근피 추출물(HU200, HU400)을 투약한 그 룹의 경우 $\mathrm{H}$ 군보다 유의적으로 체중이 감소된 것을 확인 하였다. 체중 증가량과 식이 섭취량의 비율로 살펴본 식 이효율은 $\mathrm{N}$ 군에 비해 $\mathrm{H}$ 군에서 유의적으로 증가된 것을 확인하였고, HG200, HU200, HU400의 군에서는 사료효율 이 다소 감소하는 경향을 보였다.

\section{유근피 추출물이 고지방으로 유도된 흰쥐의 장기 및 지 방조직 무게에 미치는 영향}

단위 체중 당 장기 및 지방조직 무게는 Table 3에 나타 내었다. 체중 $100 \mathrm{~g}$ 당 무게로 환산한 장기의 중량을 비교 한 실험에서 간, 부고환지방, 복부지방 무게가 $\mathrm{H}$ 군에서

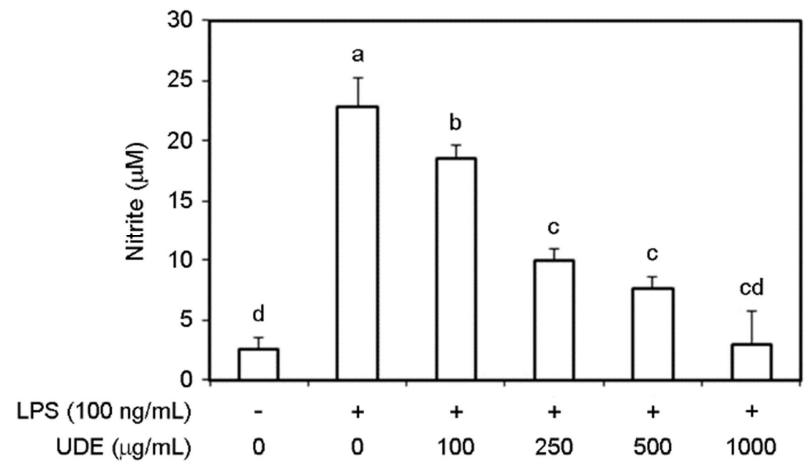

Fig. 4. Effect of UDE (Ulmus divididiana var. japonica extracts) on NO production in LPS-stimulated microglial BV-2 cells. BV-2 Cells were treated with UDE at various concentrations (100, $250,500,1,000 \mu \mathrm{g} / \mathrm{mL})$ with or without LPS $(100 \mathrm{ng} / \mathrm{mL})$ for $24 \mathrm{~h}$. The nitrite in the culture supernatant was evaluated using Griess reagent. Values with a common superscript letter within the same column are significantly different $(P<0.05)$.

Table 2. Body weight gain, food intake, and FER

\begin{tabular}{lccc}
\hline \hline Groups $^{1)}$ & Body weight gain (g/8 weeks) & Food intake (g/day) & FER $^{4)}$ \\
\hline $\mathrm{N}$ & $256.74 \pm 21.83^{\mathrm{b} 2}$ & $\left.19.92 \pm 2.00^{\mathrm{ns} 3}\right)$ & $24.34 \pm 1.32^{\mathrm{c}}$ \\
$\mathrm{H}$ & $299.88 \pm 15.60^{\mathrm{a}}$ & $16.42 \pm 2.81$ & $31.87 \pm 1.14^{\mathrm{a}}$ \\
HG200 & $266.56 \pm 12.33^{\mathrm{b}}$ & $16.09 \pm 5.68$ & $28.21 \pm 1.15^{\mathrm{b}}$ \\
HU200 & $258.96 \pm 25.86^{\mathrm{ab}}$ & $17.90 \pm 2.37$ & $27.14 \pm 1.97^{\mathrm{bc}}$ \\
HU400 & $258.02 \pm 15.00^{\mathrm{b}}$ & $18.64 \pm 2.26$ & $26.18 \pm 0.86^{\mathrm{c}}$ \\
\hline
\end{tabular}

${ }^{1)} \mathrm{N}$ : 10\% low fat diet, $\mathrm{H}: 45 \%$ high fat diet, HG200: $45 \%$ high fat diet + garcinia extracts $200 \mathrm{mg} / \mathrm{kg} / \mathrm{day}$, HU200: high fat diet + Ulmus divididiana var. japonica extracts $200 \mathrm{mg} / \mathrm{kg} / \mathrm{day}$, HU400: high fat diet + Ulmus divididiana var. japonica extracts $400 \mathrm{mg} / \mathrm{kg} / \mathrm{day}$

${ }^{2)}$ The values are mean \pm S.D. $(\mathrm{n}=6)$. Values with a common superscript letter within the same column are significantly different $(P<0.05)$

${ }^{3)}$ ns: not significant

4) FER: food efficiency ratio = body weight gain / food intake 
Table 3. Different organ weights of rats

(unit: \%)

\begin{tabular}{lccccc}
\hline \hline Groups $^{1)}$ & Liver & Spleen & Kidney & Epididymal fat & Abdominal fat \\
\hline $\mathrm{N}$ & $2.35 \pm 0.17^{\mathrm{ab} 2)}$ & $0.24 \pm 0.04^{\mathrm{ns} 3)}$ & $0.65 \pm 0.05^{\mathrm{ns}}$ & $1.53 \pm 0.38^{\mathrm{b}}$ & $1.86 \pm 0.39^{\mathrm{b}}$ \\
$\mathrm{H}$ & $2.59 \pm 0.14^{\mathrm{a}}$ & $0.19 \pm 0.04$ & $0.57 \pm 0.04$ & $2.35 \pm 0.24^{\mathrm{a}}$ & $3.08 \pm 0.64^{\mathrm{a}}$ \\
$\mathrm{HG} 200$ & $2.30 \pm 0.07^{\mathrm{b}}$ & $0.19 \pm 0.04$ & $0.62 \pm 0.04$ & $2.23 \pm 0.26^{\mathrm{a}}$ & $2.69 \pm 0.36^{\mathrm{a}}$ \\
HU200 & $2.27 \pm 0.13^{\mathrm{b}}$ & $0.21 \pm 0.03$ & $0.61 \pm 0.09$ & $2.39 \pm 0.45^{\mathrm{ab}}$ & $2.61 \pm 0.56^{\mathrm{ab}}$ \\
HU400 & $2.39 \pm 0.16^{\mathrm{ab}}$ & $0.20 \pm 0.04$ & $0.59 \pm 0.10$ & $1.75 \pm 0.18^{\mathrm{b}}$ & $1.86 \pm 0.34^{\mathrm{b}}$ \\
\hline
\end{tabular}

${ }^{1)} \mathrm{N}$ : 10\% low fat diet, H: 45\% high fat diet, HG200: 45\% high fat diet + garcinia extracts $200 \mathrm{mg} / \mathrm{kg} / \mathrm{day}$, HU200: high fat diet + Ulmus divididiana var. japonica extracts $200 \mathrm{mg} / \mathrm{kg} / \mathrm{day}$, HU400: high fat diet + Ulmus divididiana var. japonica extracts $400 \mathrm{mg} / \mathrm{kg} / \mathrm{day}$

${ }^{2)}$ The values are mean \pm S.D. $(n=6)$. Values with a common superscript letter within the same column are significantly different $(P<0.05)$

${ }^{3)}$ ns: not significant

A

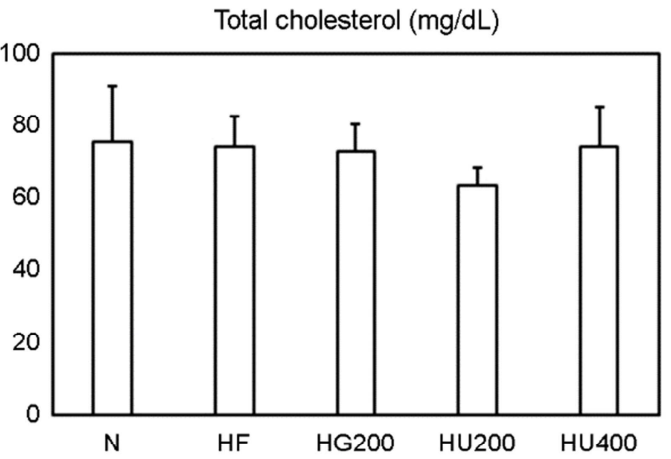

C

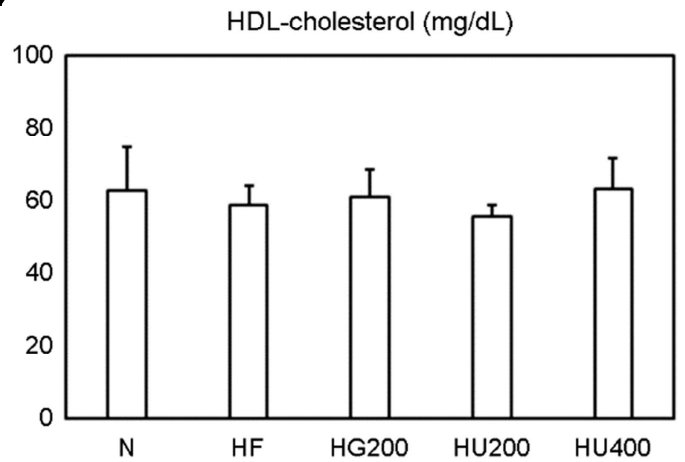

B

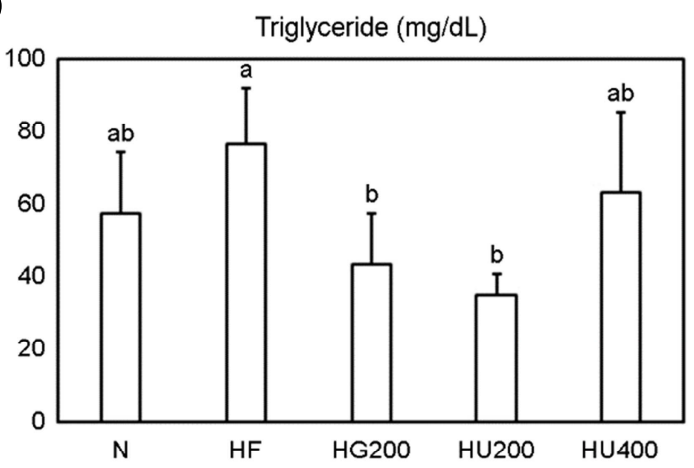

D

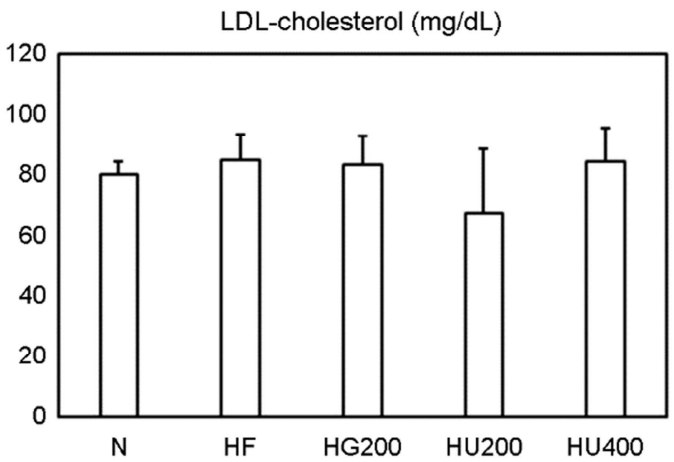

Fig. 5. Effects of UDE (Ulmus divididiana var. japonica extracts) on total cholesterol (A), triglyceride (B), HDL-cholesterol (C), and LDL-cholesterol (D) rats fed a high fat diet for 8 weeks. The values are mean \pm S.D. $(n=6)$. Values with a common superscript letter within the same column are significantly different $(P<0.05)$.

유의적으로 증가되었으며 HG200, HU200, HU400의 군에 서는 간의 무게가 유의적으로 감소된 것을 확인하였다. 특히, 부고환지방 및 복부지방의 경우 $\mathrm{HU} 400$ 군에서 $\mathrm{H}$ 군에 비해 유의성 있는 무게 감소를 확인하였다. 그러나 비장과 신장은 모든 군에서 유의한 차이가 보이지 않았다.

\section{혈중지질 농도}

고지방식이와 유근피 추출물을 첨가하여 8 주간 급여한 흰쥐의 혈청 중 총 콜레스테롤, 중성지질, $\mathrm{HDL}$-콜레스테 롤, LDL-콜레스테롤 함량은 Fig. 5 와 같다. 혈청 중 중성 지질 함량은 $\mathrm{H}$ 군에서 $76.56 \pm 15.46 \mathrm{mg} / \mathrm{dL}$ 로 $\mathrm{N}$ 군 $(57.31$ $\pm 17.05 \mathrm{mg} / \mathrm{dL}$ ) 보다 혈중 중성지질 농도가 높아졌음을 

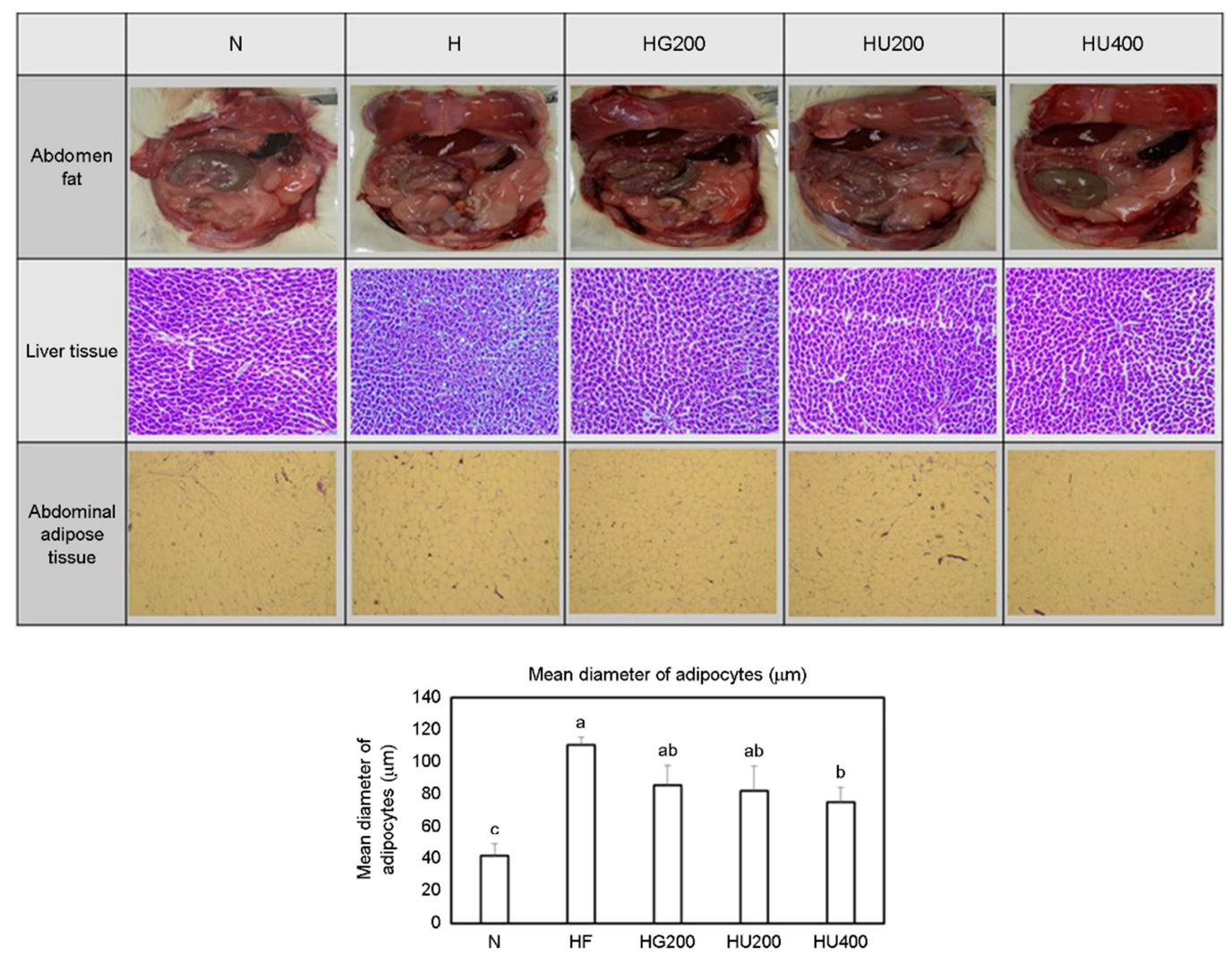

Fig. 6. Gross appearance of abdomen and effects of UDE (Ulmus divididiana var. japonica extracts) on liver and abdominal adipose tissue morphology. Hematoxylin and eosin (H\&E)-stained photomicrographs of liver and abdominal adipose sections are shown at 200X. Values with a common superscript letter within the same column are significantly different $(P<0.05)$.

확인하였다. 양성대조군인 가르시니아 추출물을 투약한 $\mathrm{HG} 200$ 군은 $43.50 \pm 14.20 \mathrm{mg} / \mathrm{dL}$ 로 $\mathrm{H}$ 군에 비해 유의적으로 감소된 것을 확인하였고, 유근피 추출물을 투약한 HU200 과 $\mathrm{HU} 400$ 군이 각각 $34.96 \pm 5.61 \mathrm{mg} / \mathrm{dL}, 63.34 \pm 21.93 \mathrm{mg} / \mathrm{dL}$ 로 유의적으로 감소된 것을 확인하였다(Fig. 5B). 그 외 총 콜레스테롤, $\mathrm{HDL}$-콜레스테롤, $\mathrm{LDL}-$ 콜레스테롤 함량은 각 군별 유의한 차이가 나타나지 않았다(Fig. 5A, 5B, 5C).

\section{지방 침착 및 조직의 형태학적 관찰}

Fig. 6은 유근피 추출물이 흰쥐의 복부 및 장기의 지방 침착 정도와 간, 복부지방 조직의 형태에 미치는 영향을 $\mathrm{H} \& \mathrm{E}$ 염색으로 살펴본 결과이다. 그림에서 보는 바와 같 이 $\mathrm{N}$ 군에 비해 $\mathrm{H}$ 군에서 복부 및 장기 주변으로 지방 침 착이 증가된 것을 확인할 수 있고, 가르시니아 추출물과 유근피 추출물을 투약한 군에서는 $\mathrm{H}$ 군에 비해 지방 침착 이 감소된 것을 확인할 수 있었다. 간 조직의 염색결과에 서 육안으로 관찰 시, $\mathrm{N}$ 군에 비해 $\mathrm{H}$ 군에서 많은 지방들
이 관찰되었지만, HG200, HU200, HU400 군에서는 지방 구가 N군의 수준으로 현저하게 줄어든 것을 확인할 수 있었다. 복부지방 size를 비교한 결과 $\mathrm{H}$ 군 $(110.21 \mu \mathrm{m})$ 보 다 $\mathrm{HU} 400$ 군 $(75.12 \mu \mathrm{m})$ 의 지방 size가 유의적으로 줄어든 것을 확인할 수 있었다.

\section{고 찰}

본 연구는 유근피 추출물의 만성질환의 예방, 치료제 및 건강기능식품으로서의 활용 가능성을 평가하기 위해 유근 피 에탄올 추출물을 대상으로 항산화, 항염, 항비만의 다 양한 생리활성을 검정하였다. 많은 연구자들로부터 천연 소재의 자원 활용성 및 이용성 등을 연구하는 주된 이유 는, 식물에 널리 분포되어 있는 페놀성 물질 때문이라 할 수 있다(Nakatani, 1990). 페놀성 물질은 phenolic hydroxyl 그룹 때문에 단백질 또는 효소 단백질, 기타 거대분자들 과 결합하여 항산화, 항염, 항암, 항비만 등의 다양한 생리 
활성을 나타낸다(Lee et al., 2005). 유근피 에탄올 추출물의 총 페놀 함량과 플라보노이드 함량을 측정한 결과, 각각 $184.68,9.25 \mathrm{mg} / \mathrm{g}$ 의 농도로 함유하고 있음을 확인하였다 (Fig. 1). 이는 Kim 등(Kim et al., 2015)이 보고한 추출조건 별 총 페놀 함량이 $215.7 \sim 363.5 \mathrm{mg} / \mathrm{g}$ 의 보인 결과보다는 낮은 함량을 나타냈지만, Jeong과 Kim (Jeong and Kim, 2012) 및 Kim 등(Kim et al., 2012)이 보고한 유근피 70\% 에탄올 추출물의 총 페놀 함량(각각 $17.9,7.1 \mathrm{mg} / \mathrm{g}$ )보다 높 게 나타났다. 이는 유근피의 추출방법 및 자생환경에 총 페놀 함량의 변화에 큰 영향을 받는 것으로 예상된다.

유근피 추출물의 항산화 활성은 DPPH radical 소거능으 로 평가하였다. Fig. 2에서 보듯이 유근피 추출물은 $50 \mu \mathrm{g}$ $/ \mathrm{mL}$ 의 농도에서 $82.15 \%$ 의 높은 소거능을 보였다. Jung 등 (Jung et al., 2008)은 유근피를 70\% 메탄올로 추출하였을 때 flavonoid 성분인 (-)-catechin 성분이 높은 DPPH radical 소거능을 보인다고 보고하였으며, Bong과 Park (Bong and Park, 2010)은 유근피에서 추출한 페놀 성분이 ROS 생성 과 관련된 산화 효소 저해 효과를 보인다고 보고하였다. 따라서 유근피의 항산화 활성은 페놀 및 플라보노이드 성 분 때문인 것으로 예상된다.

염증반응의 지표로 알려진 $\mathrm{NO}$ 는 생체 내 염증반응 시 대식세포에서 과량 생산되어 다양한 염증반응을 초래한 다고 알려져 있다(Kundu and Surh, 2008). 유근피 추출물의 항염증 활성 효과를 측정하기 위해 BV-2 cell에 LPS를 처 리하여 인위적으로 염증반응을 유도시킨 후 유근피 추출 물을 처리하여 $\mathrm{NO}$ 의 생성 억제 효과를 측정한 결과, 유 근피 추출물의 처리 농도 의존적으로 LPS에 의한 $\mathrm{NO}$ 의 생성을 유의적으로 억제하였으며(Fig. 4), 모든 농도에서 세포 독성을 나타내지 않았기에(Fig. 3) NO 생성 억제가 유근피 추출물의 효능에 의해 억제되었음을 확인할 수 있 었다.

유근피 추출물의 항비만 효과를 확인하고자 SD 계열의 흰쥐를 이용하여 고지방식이로 8 주간 사육한 동물의 체 중변화를 Table 2에 나타내었다. 저지방식이를 섭취한 N 군에 비해 고지방식이를 섭취한 $\mathrm{H}$ 군에서 체중 증가율이 유의적으로 약 $43.14 \mathrm{~g}$ 증가된 것을 확인하였다. 이는 4주 령부터 7주간의 고지방식이 섭취가 체지방 축적을 증가시 켜 체중이 증가된다는 연구결과(Chio et al., 2000)와 유사하 였다. 식이 섭취량은 저지방식이군 $(\mathrm{N})$ 과 비교하여 고지방 식이군(H, HG200, HU200, HU400)에서 다소 감소하는 경향 을 보였다. 이는 고지방식이의 섭취로 인한 열량 증가의 균형을 맞추기 위한 적응현상이라고 사료된다. 또한, $\mathrm{H}$ 군
의 식이효율의 유의적 증가는 고지방 섭취로 인한 결과 로 보인다. 또한 식이효율은 비만을 나타내는 하나의 척 도로 식이효율 수치가 작을수록 비만조절 효과가 더 크 다고 볼 수 있는데 H군에 비해 HG200, HU200, HU400군 은 유의적으로 식이효율이 감소된 것으로 보아 유근피 추 출물이 식이효율을 감소시켜 체중을 감소시킨 것으로 사 료된다.

일반적으로 고지방식이 섭취 증가는 간의 지질대사의 문제를 초래하여 간의 콜레스테롤 함량 및 간 무게가 증 가되어 진다고 보고되고 있다(Kim et al., 2011). 본 연구에 서도 $\mathrm{N}$ 군에 비해 $\mathrm{H}$ 군에서 간의 무게가 유의적으로 증가 됨을 확인하였다(Table 3). 이에 반해, 유근피 추출물을 섭 취한 HU200, HU400 군에서는 간 무게가 유의적으로 감 소됨을 확인하였다. 그 외 신장과 비장은 군별 무게 차이 가 없었지만, 부고환지방 및 복부지방의 경우 HU400군에 서 $\mathrm{H}$ 군에 비해 유의성 있는 무게 감소를 확인하였다. 비 만은 일반적으로 체지방의 증가가 체중의 증가보다 건강 에 위험한 요소로 작용한다고 알려져 있다(Park et al., 2010). 하지만 본 연구결과를 근거로 유근피의 섭취는 체지방의 증가를 감소시킬 수 있을 것으로 사료된다.

혈중 지질대사와 관련된 생화학지표인 총 콜레스테롤, 중성지질, $\mathrm{HDL}$-콜레스테롤, $\mathrm{LDL}$-콜레스테롤을 분석한 결 과 지표들 중 중성지질 함량이 $\mathrm{H}$ 군에서 $76.56 \pm 15.46 \mathrm{mg}$ $/ \mathrm{dL}$ 로 $\mathrm{N}$ 군 $(57.31 \pm 17.05 \mathrm{mg} / \mathrm{dL})$ 보다 혈중 중성지질 농도 가 높아졌지만 유근피 추출물을 투약한 군에서 유의적으 로 감소됨을 확인하였다(Fig. 5B). 이는 Lee 등(Lee et al., 2011)이 복부지방이 축적된 사람들에게서 혈중 중성지질 의 함량이 높다고 보고한 바와 같이 본 연구에서도 복부 지방이 가장 무거웠던 $\mathrm{H}$ 군이 혈청 중 중성지질 함량이 가장 높았고, 유근피 추출물을 섭취한 군의 경우 복부지 방과 중성지질 함량이 동일한 경향으로 감소됨을 확인하 였다.

복부 및 장기에 침착된 지방조직에 대해 육안적 관찰 결과, $\mathrm{N}$ 군의 부위별 지방 침착에 비해 $\mathrm{H}$ 군의 지방 침착이 증가되었음을 확인할 수 있었으며, HU200, HU400군에서 는 지방 침착이 육안적으로 감소되었음을 확인할 수 있 었다(Fig. 6). 간 조직에서도 $\mathrm{H}$ 군에서 지방구가 가장 많이 축적되었으며, 지방구의 크기도 가장 큰 것으로 관찰되었 다. 이에 반해, 유근피 추출물 투약을 통해 지방구가 감소 됨을 확인하였고, 복부지방의 크기변화도 간 조직과 유사 한 경향으로 감소되는 것으로 나타났다. 고지방 섭취로 인해 체중, 혈중지질, 체지방 침착 정도가 유근피 추출물 
로 인해 경감되는 것을 확인하였고, 이러한 결과는 추후 항비만 소재로의 개발 가능성을 보여주었다.

결론적으로 유근피 에탄올 추출물은 free radical 소거능 에 의한 항산화 활성, $\mathrm{NO}$ 소거능에 의한 항염증 활성, 고 지방식이로 유도된 동물실험에서의 항비만 효과가 각각 확인이 되어 향후 천연물 의약품 또는 건강기능식품 소재 로 개발이 가능할 것으로 사료된다.

\section{ACKNOWLEDGEMENT}

This work was supported by the National Research Foundation of Korea (NRF) grant funded by the Korea government (MOE) (No. NRF-2016R1A6A3A11935472 and NO. NRF2018R1D1A3B07051270).

\section{CONFLICT OF INTEREST}

No potential conflict of interest relevant to this article was reported.

\section{REFERENCES}

Bong JG, Park Y. Antioxidant effect of hederagenin 3-O-b-Dglucopyranosyl $(1 \rightarrow 3)$-a-L-rhamnopyranosyl $(1 \rightarrow 2)$-a-L-arabino pyranoside (HDL) isolated from root bark of Ulmus davidiana. J Life Sci. 2010. 20: 281-291.

Bray GA. A concise review on the therapeutics of obesity. Nutrition. 2000. 16: 953-960.

Chio MY, Dhoi EJ, Lee E, Park HJ. Effect of oenanthe javanica sap on plasma lipid composition in rats with high-eat diet. Korean J Plant Res. 2000. 13: 54-60.

Folin O, Denis W. On phosphotungstic-phosphomolybdic compounds as color reagents. J Biol Chem. 1912. 12: 239-249.

Friedewald WT, Levy RI, Fredrickson DS. Estimation of the concentration of low-density lipoprotein cholesterolin plasma, without use of the preparative ultracentrifuge. Clin Chem. 1972. 18: 499-502.

Green LC, Wagner DA, Glogowski J. Analysis of nitrate, and $[15 \mathrm{~N}]$ nitrate in biological fluids. Anal Biochem. 1982. 126: 131-138.

Hong ND, Roh YS, Kim NJ, Kim JS. A study on efficacy of Ulmi cortex. Korean J Pharma. 1990. 1: 217-222.

Jahromi F, Ray AB, Chansouria JPN. Antihyperlipidemic effect of flavonoids from Pterocarpus marsupium. J Nat Prod. 1993. 56: 989-994.
Jeong KY, Kim ML. Physiological activities of Ulmus pumila L. extracts. Korean J Food Preserv. 2012. 19: 104-109.

Ji HJ, Lee SI. Korea pharmacopoeia Herb medicine standard (Herb medicine). Korea Medi Indekseusa. 1988. 295.

Jung MJ, Heo SI, Wang MH. Free radical scavenging and total phenolic contents from methanolic extracts of Ulmus davidiana. Food Chem. 2008. 108: 482-487.

Kim AR, Hwang YG, Lee JJ, Jung HO, Lee MY. Effects of Eriobotrya japonica lin (loquat) leaf ethanol extract on cholesterol and antioxidative activity in rats fed a high -fat/high cholesterol diet. J Korean Soc Food Sci Nutr. 2011. 40: 673 -681 .

Kim JM, Cho ML, Seo KE, Kim YS, Jung TD, Kim YH, Kim DB, Shin GH, Oh JW, Lee JS, Lee JH, Kim JY, Lee DW, Lee OH. J Korean Soc Foood Sci Nutr. 2015. 44: 1172-1179.

Kim KB, Jo BS, Park HJ, Park KT, An BJ, Ahn DH, Kim MU, Chae JW, Cho YJ. Healthy functional food properties of phenolic compounds isolated from Ulmus pumila. Korean J Food Preserv. 2012. 19: 909-918.

Kopelman PG. Obesity as a medical problem. Nature. 2000. 404: 635-643.

Kundu JK, Surh YJ. Inflammation: gearing the journey to cancer. Mutat Res. 2008. 659: 15-30.

Lee JJ, Park MR, Kim AR, Lee MY. Effects of ramie leaves on improvement of lipid metabolism and anti-obesity effect in rats fed a high fat/high cholesterol diet. Korean J Food Sci Technol. 2011. 43: 83-90.

Lee MK, Sung SH, Lee HS, Cho JH, Kim YC. Lignan and neolignan glycosides from Ulmus davidiana var. japonica. Arch Pharm Res. 2001. 24: 198-201.

Lee SO, Lee HJ, Yu MH, Im HG, Lee IS. Total polyphenol contents and antioxidant activities of methanol extracts from vegetables produced in Ullung island. Korean J Food Sci Technol. 2005. 37: 233-240.

Mosmann T. Rapid colorimetric assay for the cellular growth and survival. J Immunol Methods. 1983. 65: 55-63.

Nakatani N. Recent advances in the study on natural antioxidants. Nippon Shokuhin Kogyo Gakkaishi. 1990. 37: 569-576.

Nieva Moreno MI, Isla MI, Sampietro AR, Vattuone MA. Comparison of the free radical-scavenging activity of propolis from several regions of Argentina. J Ethnopharmacol. 2000. 71: 109 -114 .

Ohara Y, Peterson TE, Harrison D. Hypercholesterolemia increase endothelial superoxide anion production. J Clin Inverst. 1993. 91: 2546-2551. 
Park PJ, Kim CW, Cho SY, Rha CY, Seo DB, Lee SJ. Aqueous spray-dried green tea extract regulates body weight and epididymal fat accumulation in mice. Korean J Food Sci Technol. 2010. 42: 103-108.

Shin MK. Clinical traditional hergalogy. Younglimsa, Seoul Korea. 1977. 669-778.

Takeshi T, Keisuke N, Takaaki I, Makoto Y, Tatsuji N. Involvement of adhesion molecule in in vitro plaque-like formation of macrophages stimulated with Aggregatibacter actinomycetemcomitans lipopolysaccharide. J Periodontal Res. 2010. 45: 550 -556 .

Tak PP, Firestein GS. NF-kappa B: a key role in inflammatory diseases. J Clin Investig. 2001. 107: 7-11.

Talalay P, Benson AM. Elvation of quinone reductase activity by anticarcinogenic antioxidants. Adv Enzym Regul. 1982. 20: 287-300.

Wefers H, Komai T, Talalay P, Sies H. Protection against reactive oxygen species by $\mathrm{NAD}(\mathrm{P}) \mathrm{H}$ quinone reductase induced by the dietary antioxidant butylated hydroxyl anisole (BHA). FEBS. 1984. 169: 63-66.

Yang Y, Hyun JW, Lim KH, Kim HJ, Woo ER, Park J. Antineoplastic effect of extracts from traditional medical plants and various plants (III). Korea J Pharma. 1996. 27: 105-110.

Yuan HD, Shin EJ, Chung SH. Anti-diabetic effect and mechanism of Korean red ginseng in C57BL/KsJ db/db mice. J Ginseng Res. 2008. 32: 187.

https://doi.org/10.15616/BSL.2019.25.3.227

Cite this article as: Lee SG, Kang $\mathrm{H}$. Anti-oxidant, Anti-inflammatory, and Anti-obesity Effects of Ethanol Extracts from Ulmus divididiana var. japonica. Biomedical Science Letters. 2019. 25: 227-236. 